\section{Response of common bean progenies for water use efficiency}

\author{
Dayane Cristina Lima ${ }^{1 *}$, Ângela de Fátima Barbosa Abreu² and \\ Magno Antonio Patto Ramalho ${ }^{1}$
}

\begin{abstract}
Our aim in this study was to evaluate common bean progenies for water use efficiency (WUE) and verify if selection carried out under conditions without water limitation reflects the selection carried out under stress conditions. Eighty progenies from the BRSMG Talismã $x$ G4280 cross and 80 from the BRSMG Talismã $x$ G6492 cross were evaluated with high water availability (HWA) and low water availability (LWA) in two locations and two years. Genetic variance, heritability, accuracy, expected gain from selection, correlated response to selection, genetic correlation between HWA and LWA and between the two traits evaluated, and risk index in the recommendation (RI) were estimated. Some progenies had a RI close to zero, were tolerant in LWA, and were responsive in HWA. Progenies with high grain yield and WUE could be identified. The two conditions of evaluation were equally efficient for selection, as verified by estimates of expected gains from selection.
\end{abstract}

Keywords: Grain yield, abiotic stress, Phaseolus vulgaris $L$.

\section{INTRODUCTION}

Common bean (Phaseolus vulgaris L.) is one of the most important foods in Brazil ( $70 \%$ of Brazilians consume beans daily) and, together with rice, is the basis of the Brazilian diet. Common beans are the main source of protein for low-income families. The systems used for growing beans in Brazil are highly diverse, depending on the type of farmer and, above all, on the crop season (Carneiro et al. 2015). The crop is prominent in Brazilian agribusiness because of its adaptation to edaphic and climatic conditions, which allows production in all regions of the country. In some states, e.g., Minas Gerais, common bean can be grown practically throughout the year (Ramalho et al. 2014). However, irrigation is necessary for some periods since rainfall does not occur, and when it occurs, it is not always well distributed. Thus, over time, breeders directly or indirectly aim to select cultivars that are tolerant to water deficiency (WD) and/or have higher water use efficiency (WUE).

There is a real demand for cultivars tolerant to low water availability and this has attracted the attention of breeders (Polania et al. 2016a, Vasconcelos et al. 2018, Pereira et al. 2019). In particular, along with predictions of accentuated drought in some regions, this line of research has increased (Ceccarelli 2014, Mukeshimana et al. 2014). In general, selection for response to low water availability aims to obtain plants that tolerate WD. A smaller number of studies aim to obtain water-efficient cultivars, i.e., cultivars tolerant to low-rainfall conditions, but that respond when water availability increases.
Crop Breeding and Applied Biotechnology 20(1): e253520111, 2020 Brazilian Society of Plant Breeding. Printed in Brazil http://dx.doi.org/10.1590/198470332020v20n1a11 \title{
(1)
}




\section{Lima et al.}

The common bean breeding program in the southeastern part of the state of Minas Gerais identified the segregating populations 'BRSMG Talismã x G4280' and 'BRSMG Talismã x G6492' with greater WUE (unpublished data). Evaluating progenies of these populations under different levels of water availability is important to verify the possibility of obtaining new common bean cultivars that combine good grain yield under WD and good response in the absence of WD. Estimates of genetic and phenotypic parameters obtained in these evaluations will certainly assist in continuity of selection for higher yield and WUE in the region.

The aim of this study was to select common bean progenies with high grain yield and WUE. An additional aim was to verify if selection without water limitation reflects the selection that would be carried out under stress conditions.

\section{MATERIAL AND METHODS}

In previous stages of the common bean breeding program of the Federal University of Lavras (UFLA), twelve lines were crossed in a $6 \times 6$ partial diallel scheme. One group was composed of six lines of carioca (cream-colored with brown stripes) grain type (Carioca, Carioca MG, FT84-292, BRSMG Talismã, IAPAR 31, CNFC9506) with good adaptation in the region, and the other group, of six sources of WD tolerance (G4280, SEA-5, BAT-477, IAC-Una, G6492, Ouro Negro). The populations in the F2 generation were evaluated in two field experiments, one with sprinkler irrigation. After diallel analysis of the grain yield data, the populations from crosses between 'BRSMG Talismã x G4280' and 'BRSMG Talismã $x$ G6492' were identified as the most promising for selection of progenies under WD conditions (unpublished data), and they were used in this study.

In the $\mathrm{F}_{2}$ generation, 80 plants from the BRSMG Talismã x G4280 population and 80 plants from the BRSMG Talismã $x$ G6492 population were selected, which gave rise to the $F_{2: 3}$ progenies. These progenies were evaluated in Lavras and Patos de Minas in the $F_{2: 4}$ generation (sown in the autumn/winter season of 2014), in the $F_{2: 5}$ generation (sown in the dry season of 2015), and in the $F_{2: 6}$ generation (sown in the winter season of 2015). BRSMG Talismã, BRS Estilo, G 4280, BAT 477, Carioca, Pérola, lapar 81, BRSMG Madrepérola, and BRSMG Majestoso were used as check cultivars.

In each site and season, two experiments were set up on the same day in adjacent areas. The experiments were irrigated twice a week. In one of them, water was supplied according to crop needs, i.e., without water stress, which was denominated the condition of high water availability - HWA. In the other experiment, the plants did not receive the amount of water required (under water stress), which was denominated the condition of low water availability - LWA. The water level was established according to sprinkler irrigation time, with LWA being half the irrigation time used in HWA. Thus, in experiments with HWA, the amount of water received in the average of the two locations and three sowing seasons, including water from rainfall, was $254 \mathrm{~mm}$. Experiments with LWA aimed at a $30 \%$ reduction in available water, and the plots received $183 \mathrm{~mm}$ of water. The experimental design of each experiment was a $13 \times 13$ triple lattice. Plots consisted of a 2-m row at a spacing of $0.6 \mathrm{~m}$, without a border at the end of the plot. In each block within each replication, water collectors were set up to indicate the amount of water received.

Initially, grain yield, in $\mathrm{kg} \mathrm{ha}^{-1}$, was obtained from each plot. The amount of water received in each collector was used as a covariate for analysis of this trait. All plots within the same block were considered to have received the same amount of water. Water use efficiency - WUE (grain yield without adjustment for covariate/received water amount) was also obtained, in $\mathrm{kg} \mathrm{ha}^{-1} \mathrm{~mm}^{-1}$.

Data analysis of the two traits was performed by the mixed model approach using ASRELM software. It was initially performed in each environment (location/sowing season/water level) considering all effects as random, except the mean (Model 1). A second analysis (Model 2) was then carried out within each location / sowing season, considering all effects as random, except the mean and water level effects. For the random effects of the genotypes, with $\mathrm{g} \sim \mathrm{N}\left[0, I \otimes G_{0}\right]$, an identity matrix I, and an unstructured matrix $G_{0}$ was used. $G_{0}=\left[\begin{array}{cc}\sigma_{a_{1}}^{2} & \sigma_{a_{12}}^{2} \\ & \sigma_{a_{2}}^{2}\end{array}\right]$, where $\sigma_{a_{1}}^{2}$ is genetic variance in LWA, $\sigma$ $a_{a_{2}}^{2}$ is genetic variance in HWA, and $\sigma_{a_{12}}^{2}$ is genetic covariance between LWA and HWA. Subsequently, joint analysis was performed considering all the sites/sowing seasons and water levels as a factor of the model (Model 3). As there was no homogeneity, of the residuals for this random effect, with $\varepsilon \sim \operatorname{NMV}(0, R)$, a diagonal matrix $R$ was used, in which $\mathrm{R}=\left[\begin{array}{ccc}\sigma_{e_{1}}^{2} & & \\ & & \sigma_{e_{12}}^{2}\end{array}\right]$, where $e_{1, \ldots,} e_{12}$ are the errors associated with each environment (site / sowing season / water level). 
The estimation of variance components and standard errors of the estimates and prediction of random effects were performed using the REML/BLUP (restricted maximum likelihood/best linear unbiased prediction) procedure. The Wald hypothesis test was used to test fixed effects and the likelihood-ratio test (LRT) to test random effects.

The following estimates were made: heritability $\left(h^{2}\right)$, based on progeny average; selection accuracy; expected gain from selection; ; correlated LWA response with selection made by HWA; genetic correlation between grain yield and WUE; correlation between progeny performance in LWA and HWA at each site/sowing season, as described by Bernardo (2010); and coincidence in selection of the ten best progenies for grain yield and WUE (Hamblin and Zimmermann 1986).

The most stable progenies were selected using the graphical method proposed by Nunes et al. (2005). The method uses the sum of the standardized variables ( $\Sigma Z$ ) as a measure of the adaptability of each progeny in each environment. For that reason, the averages of progenies in each environment were standardized. As the standardized variable assumes positive and negative values, a constant of five was added to make the values always positive. Thus, the mean of the population becomes five, instead of zero. Subsequently, the sum of standardized variables ( $\Sigma Z$ ) of the progenies was obtained. With the standardized values, the risk index in the recommendation (RI) was also estimated by $\mathrm{RI}=$ $|\Sigma(Z<5)|$ Number of environments $x$ constant added , where $|\Sigma(Z<5)|$ is the sum of $Z$ estimates of environments where grain yields were below average.

\section{RESULTS AND DISCUSSION}

Considerable effort in breeding has been directed to WD tolerance (Ceccareli 2014). The procedure for conducting segregating progenies is highly variable, and the objective, in most cases, is to obtain plants that are WD tolerant for a variable time (Cattivelli et al. 2008, Beebe et al. 2013, Polania et al. 2016b). Several traits have been evaluated for assessment of WD tolerance (Asfaw and Blair 2012, Mukeshimana et al. 2014, Assefa et al. 2015). However, we only considered grain yield, since this trait depends on all the others, and yield response will reflect the action of almost all genes of the plant (Porch et al. 2009, Rosales-Serna et al. 2012, Ceccarelli 2014). Analysis of grain yield in each experiment (Model 1) showed that experimental accuracy was relatively high. Estimates of selection accuracy ranged from 69 to 94\%, showing differences among progenies in all environments (sowing seasons/locations/water levels). Accuracy greater than $50 \%$ is a favorable condition for selection (Resende and Duarte 2007).

In this type of study, water must be uniformly distributed, which does not always occur. In order to mitigate possible irregular distribution of water, collectors were spaced at regular distances inside each block, as already mentioned. This procedure had successful results, as most of the accuracy estimates were high. Water collection in plots has already been successfully performed in common bean for the purpose of improving experimental accuracy (Krause et al. 2007).

Another issue when conducting experiments under conditions with and without water limitation is that heterogeneity of residuals may occur when joint analysis is desired. In this study, there was heterogeneity of residual variances (Table 1). In order to overcome this problem, the REML procedure was used in data analysis; which can use this information for a more accurate estimation of the parameters of interest (Patterson and Thompson 1971).

Table 1. Estimates of variance components of random effects for grain yield $\left(\mathrm{kg} \mathrm{ha}^{-1}\right)$ considering the effect of water levels apart from other environmental factors (locations and sowing seasons) - model 3

\begin{tabular}{lcc}
\hline Description & Component & Standard error \\
\hline Progenies (P) & $5615.19^{*}$ & 2243.14 \\
Replication & $5635.33^{*}$ & 2180.91 \\
Block (Replication) & $10826.52^{*}$ & 1441.25 \\
P x locations/sowing seasons (A) & $37556.12^{*}$ & 4019.76 \\
P x Water levels (N) & 895.29 & 1549.30 \\
P x A x N & $36070.58^{*}$ & 3528.68 \\
Residuals & & \\
$\quad$ Low water availability (LWA) & & \\
Patos de Minas -sown April 2014 & 37075.53 & 2917.54 \\
Lavras - sown July 2014 & 199554.12 & 15383.28 \\
Patos de Minas - sown March 2015 & 35423.33 & 2835.10 \\
Lavras - sown March 2015 & 71463.22 & 5798.30 \\
Patos de Minas - sown July 2015 & 25074.83 & 2011.88 \\
Lavras - sown July 2015 & 152945.80 & 11531.33 \\
$\quad$ High water availability (HWA) & & \\
Patos de Minas -sown April 2014 & 51714.15 & 4056.02 \\
Lavras - sown July 2014 & 401020.55 & 29026.77 \\
Patos de Minas - sown March 2015 & 50258.93 & 4013.53 \\
Lavras - sown March 2015 & 85035.68 & 6839.15 \\
Patos de Minas - sown July 2015 & 256595.71 & 19865.00 \\
Lavras - sown July 2015 & 377008.83 & 27325.59 \\
\hline "Signicant by the LRT test a 5\% probabity & &
\end{tabular}

${ }^{*}$ Significant by the LRT test at $5 \%$ probability. 


\section{Lima et al.}

The effects of location and sowing season were isolated from the effect of water level $(\mathrm{N})$ in Model 3. All random components were significant, except for progenies $\mathrm{x}$ water levels (Table 1). The progeny $\mathrm{x}$ water level interaction was 6.27 times lower than genetic variance among progenies. In this study, as the most pertinent information was the progeny $x$ water level interaction, the results show that the response of the progenies coincided in the two water levels.

An analysis involving the effect of water levels within each location/sowing season (Model 2) was also carried out (Table 2). In this case, the components of the model were all significant, including the progeny $\mathrm{x}$ water level interaction, which was not significant when considering all locations and sowing seasons. Estimates of correlations between LWA and HWA conditions in each location/sowing season, most from medium to small magnitude, reinforce the existence of the progeny $x$ water level interaction (Table 2 ) and indicate that the interaction is predominantly complex. However, when the analysis was carried out with water levels apart from the other environmental factors, i.e., sowing season and location, the progeny $x$ water level interaction was not significant, as already mentioned. (Tables 2 and 3 ). In this condition, all components were isolated, and the progeny $x$ water level interaction was free of other effects, which could not be detected in analyses within each location/sowing season. However, even with the significant progeny $\mathrm{x}$ water level interaction, some progenies are among the best performers in LWA and HWA in both locations. This is likewise observed among the worst performers (Table 3). Aiming to identify the highest yielding progenies when under water limitation (LWA) but that responded to improvement of the environment (HWA), the progenies were arranged in four quadrants delimited by the average in each condition. For selection purposes, progenies of interest occupy quadrant I, called "high yielding and responsive"; they have positive BLUP in LWA and HWA (Table 3). In this situation, 17 progenies were common to both evaluation locations.

A progeny $x$ environment interaction for grain yield is a frequent occurrence in the region (Lima et al. 2014, Lima et al. 2015). In order to minimize the effect of this type of interaction, it is necessary to conduct the evaluation experiments in as many environments as possible and to identify the best progenies in the average of the environments (Lima et al. 2014, Ferreira et al. 2015). The most adapted and stable progenies in the average of the locations and sowing seasons were identified using the methodology of Nunes et al. (2005). Figure 1 shows the five best progenies and the five worst ones, considering $\Sigma Z$. The progeny with best performance (progeny 1 ) had a response better than or equal to the average in all environments, showing its stability and adaptability in the 12 environments.

The risk of progeny recommendation was estimated using the same principle. For breeders, this information is important for choosing progenies for further recommendation. In this case, it is necessary to have information involving

Table 2. Significance test of model 2 components considering the effect of water levels within each location/sowing season for grain yield, and correlation between low water availability (LWA) and high water availability (HWA) conditions

\begin{tabular}{lcccccc}
\hline \multirow{2}{*}{ Description } & \multicolumn{5}{c}{ Test } \\
\cline { 2 - 6 } & $\mathbf{1}^{\text {a }}$ & $\mathbf{2}$ & $\mathbf{3}$ & $\mathbf{4}$ & $\mathbf{5}$ \\
\hline Water levels (N) & $76.81^{+}$ & $28.10^{+}$ & $228.00^{+}$ & $52.65^{+}$ & $11.27^{+}$ & $128.6^{+}$ \\
Progenies (P) & $43.09^{*}$ & $48.82^{*}$ & $28.80^{*}$ & $23.47^{*}$ & $15.78^{*}$ & $3.83^{*}$ \\
P x N & $8.92^{*}$ & $108.65^{*}$ & $38.04^{*}$ & $5.64^{*}$ & $160.13^{*}$ & $13.22^{*}$ \\
\hline Correlation & 0.80 & 0.60 & 0.53 & 0.68 & 0.36 & 0.32 \\
\hline
\end{tabular}

1: Patos de Minas, sown April 2014. 2: Lavras, sown July 2014. 3: Patos de Minas, sown March 2015. 4: Lavras, sown March 2015. 5: Patos de Minas, sown July 2015. 6: Lavras, sown July 2015.

+ Significant by the Wald test at $1 \%$ probability.

Significant by the LRT test at $5 \%$ probability.

Table 3. Number of progenies in each quadrant in Lavras and Patos de Minas, and progenies common to both locations for grain yield

\begin{tabular}{|c|c|c|c|c|c|c|c|c|}
\hline \multirow{4}{*}{ Location } & \multicolumn{8}{|c|}{ Quadrant } \\
\hline & \multicolumn{2}{|c|}{$\mathbf{I}$} & \multicolumn{2}{|c|}{ II } & \multicolumn{2}{|c|}{ III } & \multicolumn{2}{|c|}{ IV } \\
\hline & LWA $^{1}$ & HWA $^{2}$ & LWA & HWA & LWA & HWA & LWA & HWA \\
\hline & + & + & - & + & - & - & + & - \\
\hline Patos de Minas & \multicolumn{2}{|c|}{51} & \multicolumn{2}{|c|}{30} & \multicolumn{2}{|c|}{60} & \multicolumn{2}{|c|}{28} \\
\hline Lavras & \multicolumn{2}{|c|}{51} & \multicolumn{2}{|c|}{35} & \multicolumn{2}{|c|}{52} & \multicolumn{2}{|c|}{31} \\
\hline Common & \multicolumn{2}{|c|}{17} & \multicolumn{2}{|c|}{7} & \multicolumn{2}{|c|}{20} & \multicolumn{2}{|c|}{5} \\
\hline
\end{tabular}

${ }^{1}$ LWA: Low water availability. ${ }^{2}$ HWA: High water availability. 
all environments. Progeny 1, as expected, had an estimated risk near zero (Table 4). The other four also had good performance; however, their response was below average in some environments. The control BRSMG Majestoso also showed lower RI and higher $\Sigma Z$, indicating good response. The worst performing progenies had only slightly aboveaverage response in some of the environments evaluated. Furthermore, they showed higher risk in recommendation.

The performance of the BRSMG Majestoso cultivar, which is recommended for growing in the state of Minas Gerais, is noteworthy (Abreu et al. 2007) (Figure 1, Table 4). Although it was not selected for WD tolerance, it has been intensively evaluated in the state under the most diverse growing conditions. It was surely recommended because it was superior in most of the conditions and confirmed its good performance and stability in variable environments. This was likewise the case of the BRSMG Talismã cultivar, which was one of the parents used to obtain segregating populations, due to its good wide adaptation in the state and to its results as one of the best performers. It should be noted that this cultivar comes from a recurrent selection program in which one of the parents is the BAT 477 line, which is one of the sources of drought tolerance most cited in the literature (Abreu et al. 2004, Blair et al. 2012, Müller et al. 2013). The G4280 line also
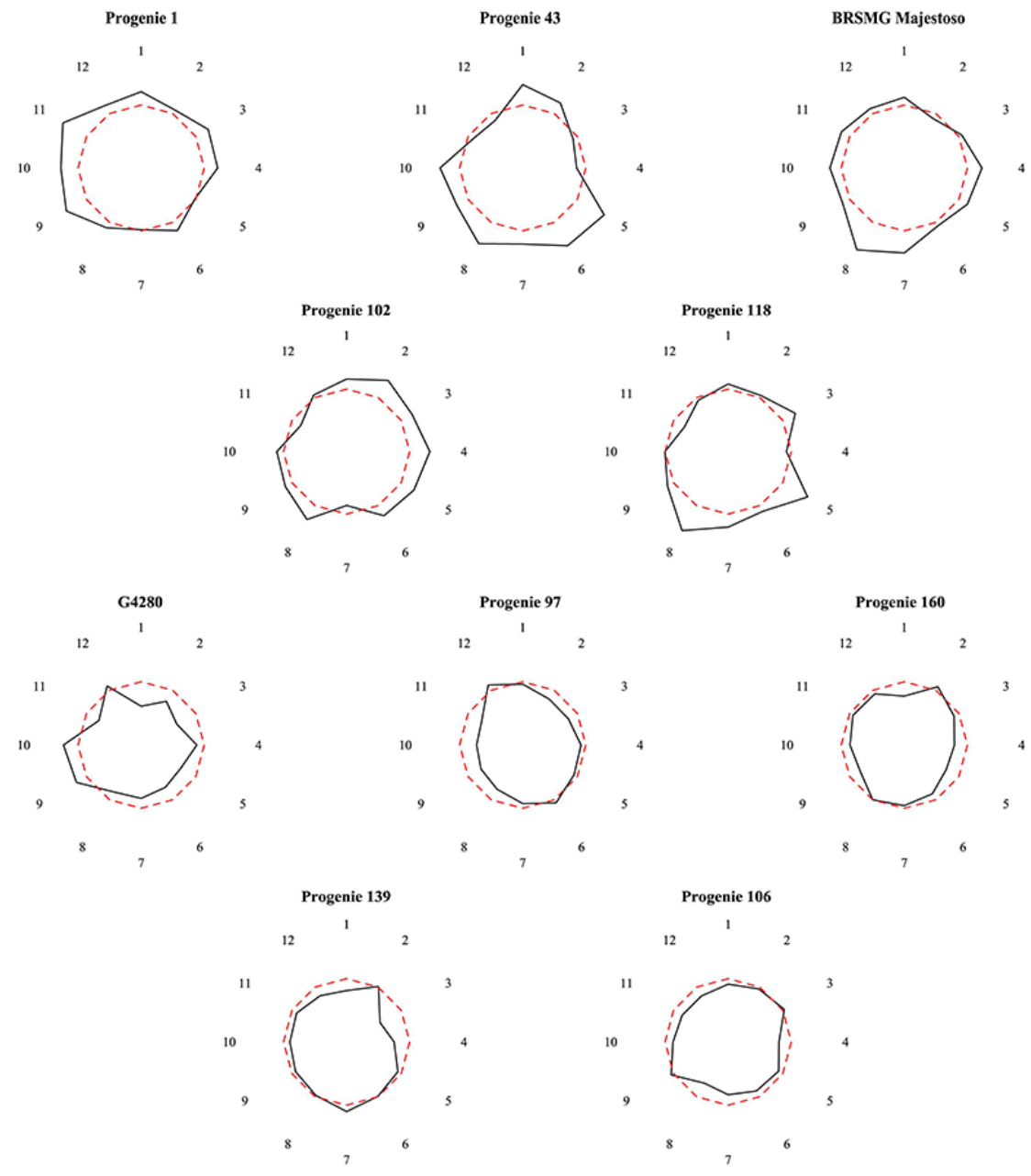

Figure 1. Graphical representation of performance of the five best and five worst progenies by $\Sigma Z$, considering grain yield. The dotted line represents the constant value (five) associated with the $Z$ variable (environment average), and the axes refer to the 12 environments [1: Patos de Minas (PM), sown April 2014 (04/14), low water availability (LWA). 2: PM, 04/14, high water availability (HWA). 3: Lavras, sown July 2014 (07/14), LWA. 4: Lavras, 07/14, HWA. 5: PM, sown March 2015 (03/15), LWA. 6: PM, 03/15, HWA. 7: Lavras, 03/15, LWA. 8: Lavras, 03/15, HWA. 9: PM, sown July 2015 (07/15), LWA. 10: PM, 07/15, HWA. 11: Lavras, 07/15, LWA. 12: Lavras, 07/15, HWA]. 
merits discussion; it was used as one of the parents because it too is a reference for drought tolerance (Guimarães et al. 2011, Asfaw and Blair 2012). In this study, this line was among the worst performers - the cultivar had a high risk of recommendation and the worst $\Sigma Z$, probably because it was not well adapted to the region. However, it confirmed its good combining ability for generating progenies with good adaptation to water limitation - progenies from a cross with this line are among those of best performance.

Information of interest to breeders is the progeny response to the additional water provided. On average, the increase per millimeter of applied water was $9.2 \mathrm{~kg}$ $\mathrm{ha}^{-1}$. The response in average yield of the progenies was always positive $\left(0.15-22.2 \mathrm{~kg} \mathrm{ha}^{-1} \mathrm{~mm}^{-1}\right)$. WUE is also information that is widely used and useful to breeders. Analyses were carried out in a manner analogous to grain yield. The results were very similar for the two traits (data not shown). The correlation between WUE and grain yield showed values higher than $98 \%$, and selection of the ten best progenies coincided in more than $88 \%$ of the cases, indicating that selection for grain yield is efficient in indirect selection for WUE.

A frequent question is whether the possibility of success in selection varies with the presence or absence of water stress (Cattivelli et al. 2008, Porch et al. 2009). To answer this question, in principle, a good estimate can be made from heritability $\left(h^{2}\right)$ for selection in the average of progenies. This information is particularly important to guide breeders regarding which environment can be more efficient for selection. Estimates were very similar for the two traits and varied according to the environment (Table 5). In joint analysis of the 12 environments, the $h^{2}$ estimate was from medium to high magnitude. Although there is divergence among $h^{2}$ estimates in LWA and HWA for grain yield and WUE, in the average of the six locations/sowing season, $h^{2}$ estimates were nearly the same, indicating that selection with a high or low water level should have the same efficiency. The results of expected gain from selection (GS) and correlated response (CR) in the LWA condition by the selection performed in the HWA condition reinforce this hypothesis.

The GS estimates were all of high magnitude, confirming the existence of genetic variation among progenies and the good experimental precision in evaluation of the two water supplies. In the average of locations and sowing seasons, GS was $35 \%$ in LWA and $29 \%$ in HWA, showing that water availability did not affect selection efficiency. In addition, when

Table 5. Heritability estimates (in percentage) for grain yield and water use efficiency in analyses in each environment and considering the 12 environments, estimates (in percentage) of gain from selection (GS) in the 12 environments, and correlated response (CR) under the condition of low water availability (LWA) by selection made under high water availability (HWA) for grain yield

\begin{tabular}{|c|c|c|c|c|c|c|c|}
\hline \multirow{2}{*}{ Location/sowing season } & \multicolumn{2}{|c|}{ Grain yield } & \multicolumn{2}{|c|}{ WUE } & \multicolumn{2}{|c|}{ GS } & \multirow[t]{2}{*}{ RC } \\
\hline & LWA & HWA & LWA & HWA & LWA & HWA & \\
\hline Patos de Minas - sown April 2014 & 56 & 73 & 56 & 73 & 18 & 21 & 7 \\
\hline Patos de Minas - sown March 2015 & 86 & 8 & 86 & 84 & 50 & 47 & 28 \\
\hline Lavras - sown March 2015 & 85 & 81 & 84 & 82 & 47 & 35 & 5 \\
\hline Patos de Minas - sown July 2015 & 89 & 79 & 89 & 78 & 53 & 38 & 21 \\
\hline Joint analysis of 12 environments & \multicolumn{2}{|c|}{49} & \multicolumn{2}{|c|}{50} & & & \\
\hline
\end{tabular}


selection was performed in HWA, the CR in LWA was always positive, although of lower magnitude than direct gain. The highest gain from selection under the HWA condition for response in LWA corresponded to $55 \%$ of gain from selection directly under the LWA condition, and the lowest gain was $11 \%$. Thus, in the case of common bean, evaluations carried out in a wide variety of environments (locations, seasons, and edaphic and climatic conditions) are efficient for the selection of progenies adapted to several conditions (Lima et al. 2014, Ferreira et al. 2015), including LWA conditions.

Breeding specifically for adaptation to water stress is considered an undesirable strategy because it is usually associated with low grain yield under favorable conditions (Ceccarelli 2014). However, breeding for wide adaptation was considered to have better cost-benefit than selection of specifically adapted progenies (Windhausen et al. 2012). Thus, the strategy used in this study of simultaneous evaluation under the two conditions of water availability, seems to be the most suitable, since it allows identification of progenies with good performance in LWA, but that also respond to improvement in the environment. However, if evaluation under controlled conditions of water availability is not possible, the use of a large number of environments may also contribute indirectly to identification of progenies that also have good grain yield under LWA. The performance of cultivars BRSMG Majestoso and BRSMG Talismã, mentioned above, confirm this observation. Other cultivars, such as Carioca and Pérola, recommended for sowing in Minas Gerais and several other states, were also considered WD tolerant in other opportunities for analysis, supporting this observation (Biudes et al. 2006).

\section{CONCLUSION}

In the average of the two sites, $10.6 \%$ of the progenies had both high yield and high WUE, that is, they were tolerant to LWA and responsive under HWA.

Selection without water limitation (HWA) reflects selection under the stress condition (LWA). The two evaluation conditions were equally efficient in selection, as shown by the estimates of GS, which were high in both LWA and HWA.

\section{REFERENCES}

Abreu AFB, Ramalho MAP, Carneiro JES, Del Peloso MJ, Paula Júnior TJ, Faria LC, Melo LC, Barros EG, Moreira MA, Pereira Filho IA, Martins M, Santos JB, Rava CA, Costa JGC and Sartorato A (2007) BRS Majestoso: another common bean cultivar of carioca grain type for the state of Minas Gerais. Crop Breeding and Applied Biotechnology 7: 403-405.

Abreu AFB, Ramalho MAP, Carneiro JES, Gonçalves FMA, Santos JB, Del Peloso MJ, Faria LC, Carneiro GES and Pereira Filho IA (2004) 'BRSMG Talismã': common bean cultivar with Carioca grain type. Crop Breeding and Applied Biotechnology 4: 372-374.

Asfaw A and Blair MW (2012) Quantitative trail loci for rooting pattern traits of common beans grown under drought stress versus non-stress conditions. Molecular Breeding 30: 681-695.

Assefa T, Wu J, Beebe SE, Rao IM, Marcomin D and Claude RJ (2015) Improving adaptation to drought stress in small red common bean: phenotypic differences and predicted genotypic effects on grain yield, yield components and harvest index. Euphytica 203: 477-489.

Beebe SE, Rao IM, Blair MW and Acosta-Gallegos JA (2013) Phenotyping common beans for adaptation to drought. Frontiers in Physiology 4: $1-20$.

Bernardo R (2010) Breeding for quantitative traits in plants. Stemma Press, Woodbury, 400p.

Biudes GB, Moda-Cirino V, Faria Rogério T and Faria Ricardo T (2006) Selection of bean cultivars for tolerance to water stress. Annual Report Bean Improvement Cooperative 49: 237-238.
Blair MW, Galeano CH, Tovar E, Torres MCM, Castrillón AV, Beebe SE and Rao IM (2012) Development of a Mesoamerican intra-gene pool genetic map for quantitative trait loci detection in a drought tolerant $\mathrm{x}$ susceptible common bean (Phaseolus vulgaris $\mathrm{L}$ ) cross. Molecular Breeding 29: 71-88.

Carneiro JES, Paula Júnior TJ and Borém A (2015) Feijão: do plantio a colheita. UFV, Viçosa, 384p.

Cattivelli L, Rizza F, Badeck FW, Mazzucotelli E, Mastrangelo AM, Francia $E$, Marè C, Tondelli A and Stanca AM (2008) Drought tolerance improvement in crop plants: An integrated view from breeding to genomics. Field Crop Research 105: 1-14.

Ceccarelli S (2014) Drought. In Jackson M, Ford-Lloyd B and Parry ML (eds) Plant genetic resources and climate change. Cabi, Boston, p. 221-235.

Ferreira RADC, Ramalho MAP, Toledo FHRB and Abreu AFB (2015) Implications of the number of years assessment on recommendation of common bean cultivars. Plant Breeding 134: 599-604.

Guimarães CM, Stone LF, Del Peloso MJ and Oliveira JP (2011) Common bean genotypes under water stress. Revista Brasileira de Engenharia Agrícola e Ambiental 15: 649-656.

Hamblin J and Zimmermann MJO (1986) Breeding common bean for yield mixtures. Plant Breeding Reviews 4: 245-272.

Krause W, Ramalho MAP and Abreu AFB (2007) Alternatives to improve the efficiency in experiments of value of cultivation and use in common bean. Ceres 54: 199-205. 


\section{Lima et al.}

Lima DC, Abreu AFB, Ferreira RADC and Ramalho MAP (2015) Breeding common bean populations for traits using selection index. Scientia Agricola 72: 132-137.

Lima LK, Ramalho MAP, Abreu AFB, Toledo FHRB and Ferreira RADC (2014) Implications of predictable and unpredictable environmental factors in common bean VCU trials in Minas Gerais. Crop Breeding and Applied Biotechnology 14: 146-153.

Mukeshimana G, Butare L, Cregan PB, Blair MW and Kelly JD (2014) Quantitative trait loci associated with drought tolerance in common bean. Crop Science 54: 923-938.

Müller BSF, Sakamoto T, Silveira RDD, Zambussi-Carvalho PF, Pereira M, Pappas Jr GJ, Costa MMC, Guimarães CM, Pereira WJ, Brondani C and Vianello-Brondani RP (2013) Differentially expressed genes during flowering and grain filling in common bean (Phaseolus vulgaris L) grown under drought stress conditions. Plant Molecular Biology Reporter 32: 438-451.

Nunes JAR, Ramalho MAP and Abreu AFB (2005) Graphical method in studies of adaptability and stability of cultivars. Annual Report Bean Improvement Cooperative 48: 182-183.

Patterson HD and Thompson R (1971) Recovery of inter-block information when block sizes are unequal. Biometrika 58: 545-554.

Pereira JF, Cunha GR and Moresco ER (2019) Improved drought tolerance in wheat is required to unlock the production potential of the Brazilian Cerrado. Crop Breeding and Applied Biotechnology 19: 217-225.

Polania J, Poschenrieder C, Beebe S and Rao IM (2016a) Effective use of water and increased dry matter partitioned to grain contribute to yield of common bean improved for drought resistance. Frontiers in Plant Science 7: 1-10.

Polania J, Rao IM, Cajiao C, Rivera M, Raatz B and Beebe S (2016b) Physiological traits associated with drought resistance in Andean and Mesoamerican genotypes of common bean (Phaseolus vulgaris L). Euphytica 210: 17-29.

Porch TG, Ramirez VH, Santana D and Harmsen EW (2009) Evaluation of common bean for drought tolerance in Juana Diaz, Puerto Rico. Journal of Agronomy and Crop Science1 95: 328-334.

Ramalho MAP, Abreu AFB and Guilherme SR (2014) Informações técnicas para o cultivo do feijoeiro-comum na região central-brasileira: 20152017. Universidade Federal de Lavras, Lavras, 168p.

Resende MDV and Duarte JB (2007) Precisão e controle de qualidade em experimentos de avaliação de cultivares. Pesquisa Agropecuária Tropical 37: 182-194.

Rosales-Serna R, Kohashi-Shibata J, Acosta-Gallegos JA, Trejo-López C, Ortiz-Cereceres J and Kelly JD (2012) Biomass distribution, maturity acceleration and yield in drought-stressed common bean cultivars. Field Crop Research 85: 203-211.

Vasconcelos UAA, Cavalcanti JJV, Farias FJC, Vasconcelos WS and Santos RC (2018) Diallel analysis in cotton (Gossypium hirsutum L.) for water stress tolerance. Crop Breeding and Applied Biotechnology 18: $24-30$.

Windhausen VS, Wagener S, Magorokosho C, Makumbi D, Vivek B, Piepho $\mathrm{H}$, Melchinger AE and Atlin GN (2012) Strategies to subdivide a target population of environments: results from the CIMMYT-led maize hybrid testing programs in Africa. Crop Science 52: 2143-2152. 